\title{
COMMUNICATION IN AND AROUND MESMERISM. CONTROVERSIES, CASE HISTORIES AND THE CULTURAL IMAGINATION
}

\author{
JÜRGEN BARKHOFF (*)
}

SUNTO. - Il mesmerismo o magnetismo animale fu il più controverso e spettacolare concetto medico fra tardo Settecento e primo Ottocento. Venne anche concettualizzato e praticato come terapia medica fondata interamente sulla comunicazione; una comunicazione che agiva a vari livelli: tra magnetizzatore e paziente, tra corpo e mente, e - nelle sue spiegazioni teoriche - tra gli esseri umani e il cosmo. Questo saggio considererà brevemente, innanzitutto, le teorie del mesmerismo da questa prospettiva, e poi tratterà alcuni degli scandalosi e provocanti fenomeni comunicativi del cosiddetto rapporto magnetico tra magnetizzatore e paziente in trance sonnambolica. Inoltre passerà brevemente in rassegna le controversie tra i sostenitori e i critici della cura magnetica circa l'esperienza comunicativa nel rapporto. La parte finale del saggio si volgerà alla letteratura romantica, in quanto le sue ricche rappresentazioni estetiche del mesmerismo trascendono le controversie illuministe e presentano più complesse, sfumate e penetranti negoziazioni delle forme di comunicazione prevalenti e osservabili nei fenomeni mesmerici. In relazione al mesmerismo possiamo così osservare che attorno al 1800 la letteratura, più della scienza medica, sembra conoscere e capire la comunicazione psicodinamica e psicofisica.

ABSTRACT. - Mesmerism or animal magnetism was the most controversial and most spectacular medical concept of the late eighteenth- and early nineteenth-century. It was also conceptualised and practiced as a medical therapy based entirely on communication; a communication that worked on many levels: between magnetiser and patient, between body and mind and - in its theoretical explanations - between human beings and the cosmos. This paper will first briefly look at theories of mesmerism from this perspective and then discuss some of the scandalous and provocative communicative phenomena of the so-called magnetic rapport between magnetiser and patient in the somnambulist trance. It will also briefly review the controversies between supporters and sceptics of the magnetic cure around the communicative experience in the rapport. The final part of this paper will turn to Romantic literature, as its rich aesthetic repre-

(*) Trinity College Dublin, The University of Dublin, Ireland. E-mail: JBRKHOFF@tcd.ie 
sentations of mesmerism transcend enlightenment controversies and offer more complex, nuanced and insightful negotiations of the forms of communication prevalent and observable in the mesmerist phenomena. In mesmerism we can thus observe that around 1800 literature seems to know and understand more about psychodynamic and psychophysical communication than medical science.

\section{Mesmerist THEORY}

Animal magnetism was developed as theory and practice by the late enlightenment medical doctor Franz Anton Mesmer. He discovered the cathartic and calming influence of 'magnetic' passes along the body of his patients during experiments with the healing power of magnets. From 1774 onwards he developed his theory of Animal Magnetism, explaining his experiences as a charismatic healer in terms of a speculative cosmological fluid theory. He saw his cures of mostly nervous complaints (and mostly in women) as effected through the workings of an ephemeral universal fluid, communicating between the macro- and microcosm and pervading the cosmos and the human body alike. The blockage or lack of this fluid in the nerves was, according to Mesmer, the cause of all illness. A magnetiser, saturated with the magnetic fluid and empowered by nature to share it, could remedy this by administering, as the positive pole, so-called magnetic strokes, pouring his excess of magnetic fluid into the needy patient, the negative pole, thus re-establishing her communication with and participation of cosmic harmony. Often these manipulations would, however, initially not cause harmonious effects at all, but rather a so-called crisis, violent convulsions that would, according to Mesmer, remove the obstacles impeding the harmonious circulation of the fluid. Mesmer saw those crises both as a symptom of disease and as the first step towards its cure. In especially susceptible patients often a gaze would suffice to evoke such a crisis, others would only fall into a deep sleep, a magnetic trance resembling what we today would call a hypnotic trance. Mesmer called this force Animal Magnetism by analogy with other imponderables pervading the nerves like electricity and galvanism ${ }^{1}$. The eighteenth century was deeply

1 For the first articulation of Mesmer's theory see F.A. Mesmer, Abbandlung über die Entdeckung des thierischen Magnetismus, Carlsruhe, Michael Macklot, 1781, Neudruck Tübingen, Edition Diskord, 1985. 
fascinated by these imponderables and speculated about them as vital forces and communicating agents that enabled a circulation between man and nature, mind and body and also from subject to subject.

The term mesmerism was later introduced by his romantic followers. Mesmer himself was a materialist, saw himself as a man of the Enlightenment, formulated his theory in the mechanistic terminology of his time and invoked Newton and Descartes as authorities. However, as he had read Philosophy at the Jesuit university at Dillingen prior to studying medicine in Vienna, pre-modern, hermetic theories of magical healing by doctor philosophers such as Paracelsus, Athanasius Kircher and van Helmont were an equally strong influence on his thinking. Additionally, his immodest claim to have found in Animal Magnetism the panacea, the alchemists' dream of a cure for all illnesses, and even more so his healing methods by touch and gaze reminded his medical colleagues of the magic-magnetic cures of baroque medicine, which modern medicine as a science was just in the process of debunking. It also brought him uncomfortably close to the countless quacks and charlatans who threatened the professionalism of enlightened medicine ${ }^{2}$.

Mesmer's most famous patient was the blind pianist Maria Theresia Paradis, a protégée of the Empress Maria Theresia, who suffered from what today would be called psychogenic blindness since the age of four, and who came to him in 1777 at the age of 18 , after being subjected to various unsuccessful cures, among them a treatment of more than 3000 electric shocks to the eyes. Mesmer's cure quickly

For the most comprehensive and final account see F.A. Mesmer, Mesmerismus. Oder System der Wechselwirkungen, Theorie und Anwendungen des thierischen Magnetismus als die allgemeine Heilkunde zur Erbaltung des Menschen, Hg. Karl Christian Wolfart, Berlin, Nikolaische Buchhandlung, 1814.

2 For authoritative accounts of the history of Animal Magnetism and Mesmerism and of Mesmer's theory see the following: A. Gauld, A History of bypnotism, Cambridge, Cambridge University Press, rev. edn 2010; F. A. Pattie, Mesmer and animal magnetism. A chapter in the history of medicine, Hamilton NY, Edmonston Publishing, 1994; M.M. Tatar, Spellbound. Studies on mesmerism and literature, Princeton NJ, Princeton University Press, 1978. H. Schott (Hg.), Franz Anton Mesmer und die Geschichte des Mesmerismus, Stuttgart, Franz Steiner, 1985, and G. Wolters (Hg.), Franz Anton Mesmer und der Mesmerismus. Wissenschaft, Scharlatanerie, Poesie, Konstanz, Universitätsverlag Konstanz, 1988 offer two rich volumes of essays in German on many aspects which in the 1980's put the discussions about mesmerism on a new footing. 
re-established a fragmentary vision and progressed well. Both the Viennese medical establishment, deeply sceptical of the magical undertones of his theory, and the pianist's parents, highly suspicious of the deep emotional bond which the magnetic rapport had established and also fearful that the empress might withdraw her pension for their daughter, turned Mesmer's triumph into a professional and personal disaster. Amidst allegations that the cure was a fraud and rumours about an affair between doctor and patient Mesmer in 1778 had to flee from Vienna to Paris ${ }^{3}$.

In pre-revolutionary France, Mesmer and his controversial cures created a veritable mesmeric craze and were hotly debated in salons, medical circles and academic societies alike, especially since one of his French followers, the Marquis de Puységur in 1784 induced a somnambulist trance in one of his patients. These trances seemed to produce an array of astounding and unexplainable 'paranormal' phenomena such as telepathy and clairvoyance, reading the magnetiser's mind and predicting the further development of illness and cure. In contrast to Mesmer, who saw the manipulations of the magnetiser as directed towards the body, Puységur understood them as affecting the psyche; this paved the way for our modern understanding of mesmerism and its presumed healing powers as an early form of hypnosis or suggestion. The magnetic trance opened a way into the unconscious; today Mesmer is, of course, acknowledged as an important precursor to Freud, and mesmerism has a central place within the history of the discovery of the unconscious. The communicative effects of the magnetic rapport, its healing potential as well as its manipulative powers, which will be discussed further below, are today understood in psychoanalytical terms as transference and as suggestive and hypnotic effects ${ }^{4}$.

3 The Paradis affair is at the heart of most contemporary fictional treatments of Mesmerism today, such as the novels The strange case of Mademoiselle P. by Brian O'Doherty (New York, Pantheon, 1992) and Am Anfang war die Nacht Musik by Alissa Walser (München, Piper, 2010), and the movies Mesmer (1994) with Alan Rickman in the title role and the recent Licht (2018) which is based on Walser's novel.

4 For authoritative accounts of Mesmer's place in psychohistory see H.F. Ellenberger, The discovery of the unconscious. The History and evolution of dynamic psychiatry, New York, Basic Books, 1970, and A. Crabtree, From Mesmer to Freud. Magnetic sleep and the roots of psychological healing, London, New Haven, 1993. 


\section{MAGNETiC MusiC}

In Paris Mesmer held court at the Place Vendôme, where the crème de la crème of pre-revolutionary France assembled around the famous baquet, which, like a Leyden jar, was meant to accumulate, intensify and distribute the magnetic fluids. Mesmer also used mirrors and music to intensify the circulation of the magnetic fluid among his patients. He himself played the glass harmonica, an instrument invented in 1761 by Benjamin Franklin as a further development of the musical glasses or glas harp which the Irishman Richard Pokrich in the 1750 's popularised as a musical instrument. The eighteenthcentury controversy about glas music in its medical as well as its aesthetic dimensions precisely mirrored debates about the salutary or detrimental effects of mesmerism. For its supporters, the glas harmonica was an instrument of unrivalled communicative immediacy. Their arguments, influenced by the age of sentimentality and drawn both from the aesthetics of music and nerve physiology of its time, broadly ran like this: As its tones were produced by the player's wet fingers on the rotating glass discs, the players emotions invested into the music could directly be transmitted from his nerves via the medium of music to the sympathetically affected nerves of the audience. For that very reason Mesmer, who was a virtuoso of glas music and introduced Mozart, a frequent guest at his house at the Wiener Landstrasse, to the instrument, used the glas harmonica in his therapeutic group sessions to support the transportation of the magnetic fluid across the room. Glas music and the magnetic fluid were seen as related media of sympathetic communication which could intensify feelings of friendship or other shared emotions such as communal acts of weeping or infectious cathartic crises around the baquet. The critiques of glas music, on the other hand, highlighted the dangers of such immediacy and warned that its shrill and wailing tones would damage the nerves. Friedrich Rochlitz summarised this view that its «play is detrimental to health, irritates the nerves too much, causes nagging melancholy and gloom and therefore is an effective means for slow emaciation» ${ }^{5}$.

5 Friedrich Rochlitz, Ueber die vermeynte Schädlichkeit des Harmonikaspiels, Allgemeine Musikalische Zeitung 1 (1798), 97-101, here 97: «ihr Spiel sey der Gesundheit schädlich, reize die Nerven zu sehr, versenke in nagende Schwermut, mache 


\section{Controversies}

The many controversies about the mesmeric cure were fought along very similar lines. The scientific establishment of the Enlightenment rejected Mesmer's theory as pure speculation and viewed his practice as fraud or at best as the result of an over-excited imagination. The authorities felt that they had to fight Mesmer: firstly as a threat to the well being of the patients, as they did not recognize the reports of his many satisfied clients about his healing successes, but on the contrary were concerned that the convulsions in the cathartic crisis were further damaging their health; secondly as a threat to science and truth, as his theory was unfounded and the existence of his ethereal fluid could not be proven; and thirdly as a threat to society, since some of his followers interpreted his understanding of the individual healing process politically and drew inspiration from it in their quest to achieve the health of society as a whole and the restoration of communication and harmony between the social classes as different parts of the body of society. In short, the authorities were suspicious that Mesmer's saloon was a center of antiroyalist conspiracy ${ }^{6}$. All these reasons prompted the authorities to act. In 1784 a high-profile commission of the most prestigious academic institution of its time, the Académie des sciences, was charged by the king to investigate Animal Magnetism, counting Benjamin Franklin, Laurent de Lavoisier (the father of modern chemistry), and the medical doctor Joseph Ignace Guillotin among its members. As this commission could not scientifically prove the existence of the postulated universal fluid, it attributed all effects of the magnetisations to the imagination, which in the same breath was branded as a dangerous force, at least when stirred up by the magnetic

deshalb düster, melancholisch, und sei ein treffliches Hülfsmittel zur langsamen Abzehrung». Translation by the author. For a more detailed discussion see J. Barkhoff, Töne und Ströme. Zu Technik und Ästhetik der Glasharmonika im Mesmerismus und bei E.T.A. Hoffmann, in Britta Herrmann, Barbara Thums (Hg.), Ästhetische Erfindung der Moderne? Perspektiven und Modelle 1750-1850, Würzburg, Königshausen \& Neumann, 2003, 165-191; for the wider context see A. Mead, Angelic music. The story of Benjamin Franklin's glas armonica, New York, Simon \& Schuster, 2016 and W. Zeitler, The glas armonica. The music and the madness, San Bernadino CA, Musica Arcana, 2013: 107-210.

6 This is the focus of the seminal study by R. Darnton, Mesmerism and the end of the Enlightenment in France, Cambridge MA, Harvard University Press, 1968. 
setting, often unleashing violent bodily reactions and uncontrollable passions. This report massively damaged and discredited the mesmeric movement. The commission with its judgement was, however, far less reductionistic and negative than the vast majority of Mesmer's enlightened opponents, who mostly saw him and his followers as clever hoaxers who were cynically exploiting the medical profession and the needs of ailing, tormented patients. Those critics denied that any of the effects of Mesmer's treatments were real in the sense that they were not faked for the purpose of making the magnetiser a rich man ${ }^{7}$.

While the commission was of course right in their rejection of the existence of the magnetic fluid, such a defensive and hostile reaction of the scientific authorities towards Animal Magnetism had deeper epistemological reasons. It posed a considerable threat to two cornerstones of the enlightened world view: the optimism that the inner workings of nature could be objectified, and the belief in the ultimate superiority of reason over the unconscious. As a result of such enlightened hostility, Animal Magnetism was discredited and practically forgotten in France and Germany between 1790 and its Romantic revival after 1800 .

\section{ROMANTIC MESMERISM}

It is easy to see why the German Romantics, on the other hand, were so attracted to mesmerism. It provided an irresistible synthesis of many of their major preoccupations: its theory and practice fused the philosophy of nature and medical anthropology with psychology and metaphysics, and also integrated the realm of the aesthetic. As the Romantics reinterpreted Mesmer's most subtle material fluid as a spiritual force, the transgressive phenomena of somnambulist trances could be taken as empirical evidence for the workings of what the pre-eminent Romantic philosopher of nature Schelling termed Weltseele or

7 For the enlightenment critics of Mesmer see the comprehensive account of A. Ego, Animalischer Magnetismus oder 'Aufklärung'. Eine mentalitätsgeschichtliche Studie zum Konflikt um ein Heilkonzept im 18. Jabrbundert, Würzburg, Königshausen \& Neumann, 1991; for a more detailed discussion of the commission's methods and findings, J. Barkhoff, Magnetische Fiktionen. Literarisierung des Mesmerismus in der Romantik, Stuttgart, Weimar, Metzler, 1995: 55-68. 
world soul ${ }^{8}$. They also offered ample opportunity to explore what Jean Paul famously called «the enormous realm of the unconscious, this true inner Africa»". Thus between 1808 and the late 1830s, for romantic philosophers of nature like Schelling and his student Gotthilf Heinrich Schubert, for key figures of romantic medicine like Christoph Wilhelm Hufeland, Karl Christian Wolfart or Carl August von Eschenmayer, and for most Romantic writers mesmerism became, as Nicholas Saul so aptly put it, «the most romantic of all sciences» ${ }^{10}$.

As the most practiced and most influential branch of Romantic medicine $^{11}$, mesmerism had many propagators among doctors, philosophers and artists, and there are dozens of theoretical treatises which undertake to explain mesmerism in the context of Romantic nature philosophy. The two most influential contributions to the theoretical debate were from the Berlin medical doctor Carl Alexander Ferdinand Kluge and the aforementioned medical doctor, nature philosopher and cultural historian Schubert. Though not a romantic in the strict sense, Kluge in 1811 published the standard reference work on animal magnetism Versuch einer Darstellung des animalischen Magnetismus als Heilmittel ${ }^{12}$. It systematised the manifold phenomena of so-called magnetic 'disorganisation' in six gradations and gave special

8 Cf F.W.J. Schelling, Von der Weltseele. Eine Hypothese der höhern Physik, zur Erklärung des allgemeinen Organismus, Hamburg, Perthes, 1798, and F.W.J. Schelling, Erster Entwurf eines Systems der Naturphilosophie, Jena, Gabler, 1799.

9 Jean Paul, Selina oder über die Unsterblichkeit der Seele, in Jean Paul, Sämtliche Werke, 1. Abt., Hg. Norbert Miller, Bd. 6, München, Wien, Hanser, 1963, 1107-1236, here 1182: «das ungeheure Reich des Unbewußten, dieses wahre innere Afrika».

10 N. Saul, Nachwort, in Saul (Hg.), Die deutsche literarische Romantik und die Wissenschaften, München, Iudicium, 1991, 306-318, here 314. For a more comprehensive discussion of Romantic theories of Mesmerism see J. Barkhoff, Magnetische Fiktionen. Literarisierung des Mesmerismus in der Romantik, cit., 85-136.

11 For an overview on romantic medicine and science see D. von Engelhardt, Natural science in the age of Romanticism, in A. Faivre, J. Needleman (eds), Modern esoteric spirituality, New York, Crossroad, 1992, 101-131, and G. Rommel, Romanticism and natural science, in D. F. Mahoney (ed.), The Literature of German romanticism. The Camden House history of German literature, vol. VIII, Rochester, Camden House, 2004, 209-227.

12 C.A.F. Kluge, Versuch einer Darstellung des animalischen Magnetismus als Heilmittel, Berlin, C. Salfeld, 1811. (Essay at an Account of Animal Magnetism as a Remedy). 
attention to the three 'higher' states of magnetic sleep in which individual sense perception was reduced or completely shut down and replaced by a heightened communicative sense of commonality or Gemeingefühl. To explain this Kluge applied Johann Christian Reil's influential bipolar model of the unconscious. According to Reil, two antagonistic nervous systems are simultaneously at work in our body. The cerebral system with the brain as its centre dominates during our waking hours, clearly differentiating between individual senses, coordinating perception and guaranteeing overall rational control. However, during sleep and related states like the magnetic trance, the other so-called ganglionic system with the solar plexus as its centre takes over, subdues the individual senses and mobilises a synthetic sixth sense, not controlled by reason, but led by intuition and seen as particularly receptive to the overall harmony of the world soul ${ }^{13}$. As a medical doctor, Kluge placed particular emphasis on the therapeutic potential of the higher gradations of magnetic sleep, especially the seeming ability to diagnose one's own illness and propose suitable cures. The philosophical potential of the magnetic sleep, however, is of course also immense. This was emphasised by Schubert, the most important populariser of nature philosophy and an ardent proponent of animal magnetism. His tremendously influential Ansichten von der Nachtseite der Naturwissenschaft ${ }^{14}$ set out to explore those aspects of natural history and anthropology which elude the reductive methodology of the 'positivistic' sciences. Animal magnetism is of course a prime example of those, and Schubert takes its transgressive somnambulist phenomena as empirical evidence for man's ability to communicate with the whole of nature in the medium of an all-pervading 'life soul'. For him the ability to perceive and interpret the workings of one's inner body seemed proof that the magnetic medium could overcome the mind-body divide. Furthermore, the 'gift' of some somnambulists to predict the further development of their cure, to divine the right therapy and to read their magnetiser's thoughts suggested that this universal force could effectively transcend time and space and (re-) connect everything with everything. Ultimately for Schubert the

13 Cf. J.C. Reil, Über die Eigenschaften des Ganglien-Systems und sein Verbältnis zum Cerebral-System, Archiv für die Physiologie 7 (1807), 189-254.

14 G.H. von Schubert, Ansichten von der Nachtseite der Naturwissenschaft, Dresden, Arnoldsche Buchhandlung, 1808. (Views of the Dark Side of Natural Science). 
magnetic trance as well as dreams, religious ecstasy, artistic inspiration, illness and even madness thus represent privileged states of awareness which allow us to achieve the highest goals of Romantic science and nature philosophy: to access the essential being of nature and even catch a glimpse of the afterlife and communicate with the "other side" ${ }^{15}$. In the work of the influential doctor, magnetizer and spiritualist Justinus Kerner mesmerism is closely linked to spiritualism, which in the nineteenth century alongside hypnosis and faith-healing becomes one of the successor movements to mesmerism ${ }^{16}$.

\section{CASE HISTORIES}

On a psychological level extensive case histories of magnetic cures, which often continued with daily sessions over months or even years, document how in this setting the reduced rational control and the patients' heightened awareness for their condition and needs allowed for constructive therapeutic insights. The majority of magnetised were young adolescent women on the threshold of physiological and social womanhood, and some of their ailments and psychosomatic complaints and the interpretations they themselves offered reveal anxieties around this transition process. Magnetisers who saw their role as 'philosophical doctors' or specialists in empirical psychology took the self-perceptions of the magnetised seriously and used the intimate bond between magnetiser and patient, the so-called 'rapport', for cautious therapeutic interventions, in some cases effectively achieving pre-Freudian 'talking cures'.

One of the most complex and most interesting of these case histories is the case of the fourteen-year-old daughter of a Heilbronn city counsellor, Lisette Kornacher. Her magnetiser was the town physician of Heilbronn, Eberhard Gmelin, a key figure among the 'philosophical

15 See G.H. von Schubert, Ansichten von der Nachtseite der Naturwissenschaft, cit., 326-360. On Schubert see the comprehensive study by S. Höppner, Natur/Poesie. Romantische Grenzgänger zwischen Literatur und Naturwissenschaft. Johann Wilhelm Ritter, Gotthilf Heinrich Schubert, Henrik Steffens, Lorenz Oken, Würzburg, Königshausen \& Neumann, 2017, 335-533.

16 See mainly J. Kerner, Die Seherin von Prevorst. Eröffnungen über das innere Leben des Menschen und über das Hereinragen einer Geisterwelt in die unsere, 2 Teile, Stuttgart/Tübingen, Cotta, 1829. 
doctors' of the late Enlightenment's anthropology movement, the most well-known pre-romantic, enlightened German magnetiser of the eighteenth century and prolific author of important and influential treatises on the subject.

Gmelin treats in his patient a persistent lung affliction, a chronic spasmic cough which, we learn, started four weeks after his patient's first menstruation. The daily magnetic sessions quickly calm the symptoms and also produce a somnambulist sleep in which Gmelin, as was customary, invites his patient to auto-diagnose her own illness. This is what she tells her doctor after she asks her mother to leave the room: When her second monthly period did not occur, the blood instead took a wrong turn in her body and travelled upwards into her lungs where it caused an obstruction. This obstruction would get worse over time, would cause increased inflammation, emaciation and a slow death ${ }^{17}$. In the context of widespread beliefs in folk medicine of the time this diagnosis of blood flows going wrong is not as far-fetched or outrageous as it may sound today. The idea that bodily fluids and especially blood could do harm and cause illness by creating blockages in the wrong parts of the body was in the eighteenth century a persistent and widespread residue of humoral pathology ${ }^{18}$. Gmelin, however, with his keen interest in empirical psychology, is skeptical towards such a pessimistic and - in the terminology of the time - melancholic diagnosis and prognosis. He decides to interpret this illness psychologically and to treat it accordingly. He understands that it is rather linked to a crisis of adolescence: the young women is frightened by the changes to her body and the prospect of becoming a women also on a social level. She thus interprets the changes in her body in the opposite direction to the normal development connected with the hormonal changes of menstruation. In their dialogues about her illness during her somnambulist trances he thus subtly but persistently steers her self-observations and interpretations in a less pessimistic direction until Lisette, reluctantly at first, but then increasingly cheerful, starts to accept and believe that she can

17 Cf. E. Gmelin, Geschichte einer magnetischen Schlafrednerin 1791, in Gmelin, Materialien für die Anthropologie, Bd. 2. Untersuchungen über den Thierischen Magnetismus und die Einfache Bebandlungsart, ibn nach gewissen Regeln zu leiten und zu handhaben, Heilbronn, Rotenburg ob der Tauber, Cotta, 1793, 1-365, here 53.

18 Cf B. Duden, Geschichte unter der Haut. Ein Eisenacher Arzt und seine Patientinnen um 1730, Stuttgart, Klett-Cotta, 1987. 
indeed be cured. After 18 months of almost daily sessions of magnetic sleep she finally predicts that her menstrual flow will soon return. When this happens, the mesmeric therapy concludes; the menstrual stream replaces the flow of the magnetic fluid and also the flow of the somnambulist narrative. When Gmelin concludes his case history by describing his patient's regained health, he also records that she has become less bashful and with a healthy degree of «more female vanity $[\ldots]$, this is now, as it should be for her age and social status, the way of the world!» ${ }^{19}$. In other words: her physical health returns together with a newly developed confidence in her new social role as a woman. A couple of years later Lisette Kornacher marries a young assistant of Eberhard Gmelin, which, one might speculate, was a way of dealing with the transference (in psychoanalytic terms) that developed during the intensive mesmeric rapport over such a long period ${ }^{20}$. What is particularly noteworthy in case histories such as this one (and there are many) is the way doctor and patient together co-create the narrative. The doctors guide those narratives with their questions and interpretative suggestions and give them their final written 'scientific' form. The patients contribute to this narrative via the imagined somnambulist 'gaze' into their own bodies, through their auto-therapy and self-medication and through their prophecies concerning how the illness will develop. They thus become agents of their own illness by giving it symbolic meaning within the context of their sense of self. These somnambulist narratives thus ultimately imbue illness with meaning and create an understanding that integrates it into a wider identity narrative.

Arguably these magnetic cures were the most advanced psychological treatments of their time. Psychiatry as an emerging discipline, which established itself in Germany mainly through Johann

19 E. Gmelin, Geschichte einer magnetischen Schlafrednerin 1791, cit., 357: «mehr weibliche Eitelkeit [...]; dies ist nun, wie es nach ihrem Alter und Stand seyn sollte, der Welt Lauf!».

20 For a more detailed analysis of this case study see J. Barkhoff, Darstellungsformen von Leib und Seele in Fallgeschichten des Animalischen Magnetismus, in HansJürgen Schings (Hg.), Der ganze Mensch. Literatur und Antbropologie im 18. Jahrbundert. DFG - Symposion 1992, Stuttgart, Metzler, 1994, 214-241. For the relationship between psychology and literature in Germany more widely see M. Bell, The German tradition of psychology in literature and thought, 1700-1840, Cambridge, Cambridge University Press, 2005. 
Christian Reil's influential Rhapsodieen über die Anwendung der psychischen Curmethode auf Geisteszerrüttungen of $1803^{21}$ and Reil's subsequent reforms of mental asylums mostly displayed an attitude much less receptive to the inside perspective of the mentally disturbed than that of 'philosophical doctors' such as Gmelin and subsequently many Romantic doctors and writers.

\section{LiterARY MESMERISM}

In his Die Symbolik des Traumes of 1814 Johann Gotthilf Schubert calls the intuitive magnetic sensorium our inner «hidden poet $\gg{ }^{22}$. The poetic imagination is indeed a rich source for our understanding of mesmerism, and its most sophisticated explorations are not to be found in speculative treatises, but in literature. Especially the authors of High and Late German Romanticism were deeply fascinated by the phenomenon and used it as a central motif in many of their texts. Most of them had read Schubert's works and many knew other specialist literature. Many Romantics such as Novalis, Jean Paul, Bettina von Arnim or Friedrich Schlegel were practising magnetisers. Their most productive mesmerist activity, however, was writing, in which they rewrote and radicalised the mesmerist discourse ${ }^{23}$.

Their main theme is the balance of power in the communicative situation of the rapport. A number of central Romantic texts reveal the manipulative potential of the rapport and thus subvert the rather optimistic anthropology of theoretical magnetism. Against the constant suspicion of sceptics that erotic attraction was the most important if not

21 J.C. Reil, Rhapsodieen über die Anwendung der psychischen Curmethode auf Geisteszerrüttungen, Halle, Cotta, 1803. (Rhapsodies on the Application of the Psychological Method for Healing Mental Disturbances).

22 G.H. von Schubert, Die Symbolik des Traumes, Bamberg, Kunz, 1814, 3: «versteckte[r] Poet». (The Symbolism of Dreams).

23 For a more comprehensive discussion of literary mesmerism see J. Barkhoff, Magnetische Fiktionen. Literarisierung des Mesmerismus in der Romantik, cit, M.M. Tatar, Spellbound. Studies on mesmerism and literature, cit., and E. Leonardy, M.F. Renard, C. Drösch, S. Vanasten (Hg.), Traces du Mesmérisme dans la littérature européenne du XIXe siècle / Einflüsse des Mesmerismus auf die europäische Literatur des 19. Jahrbunderts, Bruxelles, Publications de Facultés universitaires de Saint-Louis, 2001. 
only ingredient of the magnetic rapport all theoreticians of mesmerism protested the absolute moral integrity of the relationship between doctor and patient. Romantic authors counter this naivety with portrayals of power-seeking, self-satisfying magnetisers who cast their mesmeric spell over their victims like the Marquese in Achim von Arnim's novel Armut, Reichtum, Schuld und Sübne der Gräfin Dolores $(1810)^{24}$. He uses the dependence and vulnerability of the Countess for erotic gratification and narcissist self-aggrandizement ${ }^{25}$. The telepathic somnambulist rapport between Graf Wetter vom Strahl and the heroine of Heinrich von Kleist's Käthchen von Heilbronn (1810) ${ }^{26}$, a character inspired by Lisette Kornacher, demonstrates how the Romantic dream of immediate and absolute communication is inseparable from the nightmare of dominance and subjugation ${ }^{27}$. E.T.A. Hoffmann's Der unbeimliche Gast (1818) and even more so his Der Magnetiseur (1814) portray mesmeric communication not as a healing force, but as a manipulative power, invading and colonising the mind, and ultimately resulting in a terrifying loss of self. The latter text, especially, is a key document of literary mesmerism. Here the magnetiser Alban, a parasitic monster who feeds on the life energy of his patient Marie, treats her with mesmeric passes for a nervous disorder which he himself had caused in the first instance through that self-same magnetic mind control. He is driven by a proto-Nietzschean will to power and justifies his desire to triumph over his female victim with the gendered anthropology of his time:

24 Cf. L.A. von Arnim, Gräfin Dolores, in von Arnim, Werke, Bd.1, Hollins Liebeleben. Gräfin Dolores, Hg. Paul Michael Lützeler, Frankfurt a.M., Deutscher Klassiker Verlag, 1989, 101-684. (Poverty, Wealth, Guilt and Repentance of Countess Dolores).

25 For mesmerism in Arnim overall see Ch. Drösch, Somnambule Schwärmerei und wunderbarer Magnetismus. Künstlicher Somnambulismus und ähnliche Phänomene im Prosawerk Ludwig Achim von Arnims, Würzburg, Königshausen \& Neumann, 2012.

26 Cf. H. von Kleist, Das Käthchen von Heilbronn oder Die Feuerprobe. Ein grosses historisches Ritterschauspiel, in von Kleist, Sämtliche Werke und Briefe, Bd. 1, Hg. Helmut Sembdner, München, Deutscher Taschenbuch Verlag, 1987, 429-531.

27 For mesmerism in Kleist overall see K. Weder, Kleists magnetische Poesie. Experimente des Mesmerismus, Göttingen, Wallstein, 2008.

28 Cf. E.T.A. Hoffmann, Der unbeimliche Gast, in Hoffmann, Die Serapionsbrüder, Hg. Walter Müller-Seidel, München, 1963, 600-642. (The Uncanny Guest). 
Nature has organised the female as passive in all her tendencies. - It is this willing abandonment, this eager grasping of the other, exterior, the acceptance and veneration of the higher principle, in which the truly childlike spirit consists, and which only the female possesses. Completely to dominate and assimilate this spirit is the highest bliss ${ }^{29}$.

Alban's ruthless manipulations, which rob Marie of her free will and ultimately kill her, amount to an act of communicative vampirism ${ }^{30}$. His portrayal unmasks the ideal of the magnetiser as a benevolent and generous purveyor of vital forces as a misogynist dream of male domination.

A number of other tales like Caroline de La Motte Fouqué's novel Zauber der Natur (1810) ${ }^{31}$, Achim von Arnim's Päpstin Jobanna (1810) ${ }^{32}$, E.T.A. Hoffmann's Das öde Haus (1817) ${ }^{33}$ and also Eduard Mörike's Maler Nolten (1832) ${ }^{34}$ further highlight the central importance of the Romantic gender discourse for mesmerism by experimenting with role

29 E.T.A. Hoffmann, Der Magnetiseur, in Hoffmann, Fantasie-und Nachtstücke, Hg. Walter Müller-Seidel, München, Winkler, 1960, 141-178, (The Magnetiser), here 173: «Die Natur organisierte das Weib in allen seinen Tendenzen passiv. - Es ist das willige Hingeben, das begierige Auffassen des fremden, außerhalb liegenden, das Anerkennen und Verehren des höheren Prinzips, worin das wahrhaft kindliche Gemüt besteht, das nur dem Weibe eigen und das ganz zu beherrschen, ganz in sich aufzunehmen, die höchste Wonne ist». For mesmerism in Hoffmann overall see D. Hilpert, Magnetisches Erzäblen. E.T.A. Hoffmanns Poetisierung des Mesmerismus, Freiburg im Breisgau, Rombach, 2014.

30 For the relationship between mesmerism and vampirism see J. Barkhoff, Female vampires, victimbood and vengeance in German Literature around 1800, in Helen Fronius, Anna Linton (eds.), Women E death. Representations of female victims and perpetrators in German culture 1500-2000, Rochester, New York, Camden House, 2008, 128-143, and J. Barkhoff, Vampirismus und Mesmerismus. Parasitär-fluidale Kommunikation im Vergleich, in Christian Begemann, Britta Herrmann, Harald Neumeyer (Hg.), Dracula unbound. Kulturwissenschaftliche Lektüren des Vampirs, Freiburg im Breisgau, Rombach, 2008, 75-97.

31 Cf. C. de la Motte Fouqué, Magie der Natur. Eine Revolutionsgeschichte. Faksimiledruck nach der Ausgabe von 1812, Hg. Gerhart Hoffmeister, Bern, Peter Lang, 1989. (Magic of Nature).

32 Cf. L.A. von Arnim, Die Päpstin Johanna, in von Arnim, Sämmtliche Werke, Bd. 19, Nachlass, Bd. 2, Berlin, v. Arnims Verlag, 1846. (Pope Joan).

33 Cf. E.T.A. Hoffmann, Das öde Haus, in Hoffmann, Fantasie- und Nachtstücke. Hg. Walter Müller-Seidel, München, Winkler, 1960, 459-488. (The Desolate House).

34 Cf. E. Mörike, Maler Nolten, in Mörike, Werke und Briefe. Historisch-kritische Gesamtausgabe, Bd. 3, Hg. Herbert Meyer, Stuttgart, Klett, 1967. (Nolten the Painter). 
reversals. These texts feature female magnetisers who usurp the active and authoritative magnetiser's role which in theory and practice was an all-male reserve. Without exception they are punished for their transgressive behavior with either madness or death ${ }^{35}$.

Another aspect of literary mesmerism is more positive again and exploits the potential of mesmerism for aesthetic self-reflexivity. Most literary treatments use the parallels between aesthetic and magnetic inspiration for a self-reflection on the creative process and the rapport between text and reader. In some of his music novellas like Ritter Gluck $(1809)^{36}$ and Don Juan (1812) ${ }^{37}$ Hoffmann stresses the affinities between music as the «most romantic of all art forms $»^{38}$ and the mesmerist fluid. At their best, the most fundamental force in nature and the most artificial product of human ingenuity can work together to touch our deepest emotions, momentarily to open the soul to transcendence and foster harmony. However, his portraits of Romantic artist-magnetisers also reveal a fundamental scepticism about art's capacity to fulfil such potential in the hands of more often than not self-obsessed Romantic poets who use their art for narcissistic purposes. A similar ambivalence is at work in Achim von Arnim's early Romantic artist novel Hollins Liebeleben (1802) ${ }^{39}$ and in his Die Versöbnung in der Sommerfrische $(1812)^{40}$. However, later texts like Hoffmann's last tale Die Genesung

35 For this aspect see J. Barkhoff, Geschlechteranthropologie und Mesmerismus. Literarische Magnetiseurinnen bei und um E.T.A. Hoffmann, in Gerhard Neumann (Hg.), 'Hoffmaneske Geschichte'. Zu einer Literaturwissenschaft als Kulturwissenschaft, Würzburg, Königshausen \& Neumann, 2005, 15-42.

36 Cf. E.T.A. Hoffmann, Ritter Gluck, in Hoffmann, Fantasie- und Nachtstücke, Hg. Walter Müller-Seidel, München, Winkler, 1960, 14-24. (Knight Gluck).

37 Cf. E.T.A. Hoffmann, Don Juan, in Hoffmann, Fantasie-und Nacbtstücke, Hg. Walter Müller-Seidel, München, Winkler, 1960, 67-78.

38 E.T.A. Hoffmann, Kreisleriana, in Hoffmann, Fantasie- und Nachtstücke, Hg. Walter Müller-Seidel, München, Winkler, 1960, 27-66, here 39: «die romantischste aller Künste».

39 Cf. L.A. von Arnim, Hollins Liebeleben, in von Arnim, Werke, Bd.1, Hollins Liebeleben. Gräfin Dolores, Hg. Paul Michael Lützeler, Frankfurt a.M., Deutscher Klassiker Verlag, 1989, 9-99. (Hollin's Life of Love).

40 Cf. L.A. von Arnim, Die Versöhnung in der Sommerfrische, in von Arnim, Werke, Bd.3, Sämtliche Erzählungen 1802-1817, Hg. Renate Moehring, Frankfurt a.M., Deutscher Klassiker Verlag, 1990, 541-609. (Reconciliation at the Summer Vacation). 
$(1822)^{41}$, Jean Paul's Der Komet (1820-22) ${ }^{42}$ and Arnim's Das Majorat, also known as Die Majoratsherren (1820) ${ }^{43}$ are again more optimistic, if never unambiguously so, about the power of both art and mesmerism to help reintegrate the subject into a larger whole. In these artist-magnetisers the famous utopian hope of the early Romantic author Novalis (Friedrich von Hardenberg) that the Romantic poet might become a «transcendental physician» ${ }^{4}$, able to overcome the modern divisions within the individual and even heal the ailments of his age, tentatively reemerges. This was the ultimate communicative utopia of Romanticism, a utopia, in which mesmerism, as this brief and by no means comprehensive overview attempted to demonstrate, played an important role, albeit one which, as shown, it ultimately could not fulfil.

41 Cf. E.T.A. Hoffmann, Die Genesung, in Hoffmann, Späte Werke, Hg. Walter Müller- Seidel, München, Winkler, 1965, 623-632. (Convalescence).

42 Cf. Jean Paul, Der Komet, in Jean Paul, Sämtliche Werke. 1. Abt, Hg. Norbert Miller, Bd. 6, München, Wien, Hanser, 1963, 563-1036. (The Comet).

43 Cf. L.A. von Arnim, Die Majoratsherren, in von Arnim, Werke, Bd. 4. Sämtliche Erzäblungen 1818-1830, Hg. Renate Moehring, Frankfurt a.M., Deutscher Klassiker Verlag, 1992, 107-147 (The Inheritance).

44 Novalis, Schriften, 2. Band, Das Philosophische Werk 1, Hg. Richard Samuel in Zusammenarbeit mit Hans-Joachim Mähl und Gerhard Schulz, Darmstadt, Wissenschaftliche Buchgesellschaft, 1965, 535: «transscendentale[r] Arzt». 
